\title{
ISOTRETINOIN FOR TREATING ACNE VULGARIS
}

\author{
IRMA BERNADETTE S. SITOHANG \\ Department of Dermatology and Venereology, Faculty of Medicine, Universitas Indonesia, Dr. Cipto Mangunkusumo Hospital, Jakarta, \\ Indonesia \\ Email: irma_bernadette@yahoo.com
}

Received: 19 Oct 2020, Revised and Accepted: 17 Dec 2020

\begin{abstract}
Acne vulgaris (AV) occurs in more than $80 \%$ of dermatological cases in adolescents and young adults and affects the quality of life. Oral isotretinoin a metabolite product of vitamin A, is well-known to be the most effective treatment for severe nodulocystic AV and moderate AV that does not respond to other therapeutic modalities. Thus, this literature review was conducted to explain the mechanism of action, effectiveness, contraindications, side effects, and safety of oral isotretinoin in AV, which provided essential information for dermatologists. Furthermore, isotretinoin is the only treatment modality that has implications for the entire pathogenesis of acne. It contributes to decreasing corneocytes' adhesion, supporting cellular proliferation and follicular renewal, induction of cell apoptosis, and immune regulation. The effectiveness of AV therapy with isotretinoin has expanded as it is also indicated for moderate to severe AV that does not respond well to topical combination therapy or systemic antibiotics. However, isotretinoin is included in Category X drugs and may induce many side effects from mucocutaneous effects to teratogenicity. From this extensive literature review, it can be concluded that isotretinoin is one of the treatment modalities for acne with good effectivity due to its mechanism of actions that affect the entire acne pathogenesis. Considering the various side effects of isotretinoin, its use requires adequate clinical assessment and monitoring by a dermatologist
\end{abstract}

Keywords: Acne vulgaris, Isotretinoin, Effectiveness, Contraindications, Side effects, Safety

(C) 2021 The Authors. Published by Innovare Academic Sciences Pvt Ltd. This is an open access article under the CC BY license (https://creativecommons.org/licenses/by/4.0/) DOI: https://dx.doi.org/10.22159/ijap.2021v13i2.40045. Journal homepage: https://innovareacademics.in/journals/index.php/ijap

\section{INTRODUCTION}

Acne vulgaris (AV) is a broad-spectrum multifactorial disease. The clinical manifestations include white and black comedones, papule, pustule, node, and cyst [1]. Various triggering factors that have been identified are as follows: genetics, race, stress, diet, cosmetics, drugs, physical pressure, and smoking habits [2, 3]. Acne vulgaris occurs in more than $80 \%$ of dermatological cases in adolescents and young adults $[2,4]$. About $20-30 \%$ of moderate to severe AV develops in young adults and profoundly affects their quality of life. Some adult patients require prolonged therapy due to its persistent characteristic. $\mathrm{AV}$ management's general principles include detection of triggering factors, and combination of medications depending on pathogenesis, clinical condition, and psychological circumstances. AV medications can be adjusted according to the degree of AV severity based on Lehmann's criteria, divided into mild, moderate, and severe [5]. Table 1 outlines the recommended therapy for AV based on the American Academy of Dermatology (AAD) [6].

Adult acne vulgaris is sometimes difficult to treat, even though combinations of topical therapy and standard systemic antibiotics have been administered. The dosage of isotretinoin commonly used for $\mathrm{AV}$ is $0,5-1 \mathrm{mg} / \mathrm{kg} / \mathrm{per}$ day for $4-6 \mathrm{mo}$. As clinical trials progressed, the recent trend suggests that low doses of isotretinoin might be effective in treating acne with a lower risk of adverse effects $[4,7]$.

Table 1: Therapeutic algorithms for the management of acne vulgaris

\begin{tabular}{|c|c|c|c|c|}
\hline & Mild AV & Moderate AV & Severe AV & Ref \\
\hline $\begin{array}{l}\text { First-line } \\
\text { treatment }\end{array}$ & $\begin{array}{l}\text { Benzoyl Peroxide (BP) or } \\
\text { topical retinoid } \\
\text {-or- } \\
\text { topical combination } \\
\text { therapy** } \\
\text { BP+antibiotic or } \\
\text { retinoid+BP or } \\
\text { retinoid+BP+antibiotics }\end{array}$ & $\begin{array}{l}\text { Topical combination therapy** } \\
\text { BP+antibiotic or } \\
\text { retinoid+BP or } \\
\text { retinoid+BP+antibiotic } \\
\text {-or- } \\
\text { Oral antibiotic+topical } \\
\text { retinoid+BP } \\
\text {-or- } \\
\text { Oral antibiotic+topical } \\
\text { retinoid+BP+topical antibiotic }\end{array}$ & $\begin{array}{l}\text { Oral antibiotic } \\
+ \text { topical combination therapy** } \\
\text { BP+antibiotic or retinoid+BP or } \\
\text { retinoid+BP+antibiotic } \\
\text {-or- } \\
\text { Oral isotretinoin }\end{array}$ & [6] \\
\hline $\begin{array}{l}\text { Alternative } \\
\text { treatment }\end{array}$ & $\begin{array}{l}\text { Add topical retinoid or BP (if } \\
\text { not on already) } \\
\text {-or- } \\
\text { Consider alternative } \\
\text { retinoid } \\
\text {-or- } \\
\text { Consider topical dapsone }\end{array}$ & $\begin{array}{l}\text { Consider alternate combination } \\
\text { therapy } \\
\text {-or- } \\
\text { Consider changes in oral } \\
\text { antibiotic } \\
\text {-or- } \\
\text { Add combined oral } \\
\text { contraceptive or oral } \\
\text { spironolactone (females) } \\
\text {-or- } \\
\text { Consider oral isotretinoin }\end{array}$ & $\begin{array}{l}\text { Consider changes in oral } \\
\text { antibiotic } \\
\text {-or- } \\
\text { Add combine oral contraceptive } \\
\text { or oral spironolactone (females) } \\
\text {-or- } \\
\text { Consider oral isotretinoin }\end{array}$ & {$[6]$} \\
\hline
\end{tabular}

\footnotetext{
${ }^{* *}$ Can be prescribed as a fixed combination product or as a monotherapy. BP: benzoyl peroxide.
} 
Oral isotretinoin is well-known to be the most effective treatment for severe nodulocystic AV and moderate AV that does not respond to other therapeutic modalities. Oral isotretinoin (13-cis-retinoic acid) is the first generation of nonaromatic retinoid beta-carotene (provitamin A) [8]. Oral isotretinoin was initially approved as a treatment for severe AV by The United States Food and Drug Administration (FDA) in 1982 [7] Over the next two decades, isotretinoin is still a clinically effective anti-acne therapy resulting in long-term remission and significant improvement in many patients. As reported by $\mathrm{AAD}$, the use of oral isotretinoin is only recommended for severe $\mathrm{AV}$ or moderate $\mathrm{AV}$ as an alternative therapy [6].

This literature review was conducted to explain the mechanism of action, effectiveness, contraindications, side effects, and safety of oral isotretinoin in $\mathrm{AV}$, which provided essential information for dermatologists. Articles were obtained from PubMed and Cochrane Central databases for published articles during the past $20 \mathrm{y}$. Keywords used for this review were 'acne vulgaris' and 'isotretinoin'. Only articles written in English were included in this review.

\section{Pharmacokinetics}

Isotretinoin is a metabolite product of vitamin A and provitamin A carotenoids, which can be found in liver, milk, cheese, and green vegetables. Retinol (vitamin A) is absorbed in the gastrointestinal tract and metabolized into the retinal in the liver. Furthermore, retinal will be oxidized to retinoic acid and can be converted to one another. The two isomers (retinoic acid and 13-cis-retinoic acid/isotretinoin) have identical chemical structures but different molecular geometry, resulting in different half-life; approximately $20 \mathrm{~h}$ for isotretinoin and $0.9 \mathrm{~h}$ for retinoic acid. Isotretinoin and retinoic acid are further metabolized to oxo-isotretinoin and oxoretinoic acid, respectively. Like other retinoates, isotretinoin's lipophilic characteristic leads to a wide range of absorption levels when consumed without food. When taking them with food, the bioavailability (measured as mean maximum plasma concentration and the area under the 'plasma concentration-time' curve) increases, and the variability decreases $[9,10]$.

Isotretinoin is strongly bound ( $>95 \%$ ) to plasma protein, mostly albumin, and is not stored in adipose tissue. This has been scientifically proven by direct measurement of isotretinoin in plasma, skin, and subcutis. The concentration of isotretinoin in the skin and subcutis are lower than in plasma. In acne patients treated with oral isotretinoin, the concentration of approximately $60 \mathrm{ng} / \mathrm{g}$ and $40 \mathrm{ng} / \mathrm{g}$ were found in the epidermis and subcutis, respectively, compared to $100 \mathrm{ng} / \mathrm{ml}$ in plasma [10].

A study was conducted on acne patients using a high-performance liquid chromatography assay [11]. Fig. 1 shows the plasma concentration of isotretinoin, retinoic acid, and their metabolites in the last $4 \mathrm{w}$ of therapy with isotretinoin at an oral dose of 30 $\mathrm{mg} /$ day. During therapy, stable concentrations of oxo-isotretinoin and isotretinoin were higher than retinoic acid and oxo-retinoic acid $[10,11]$.

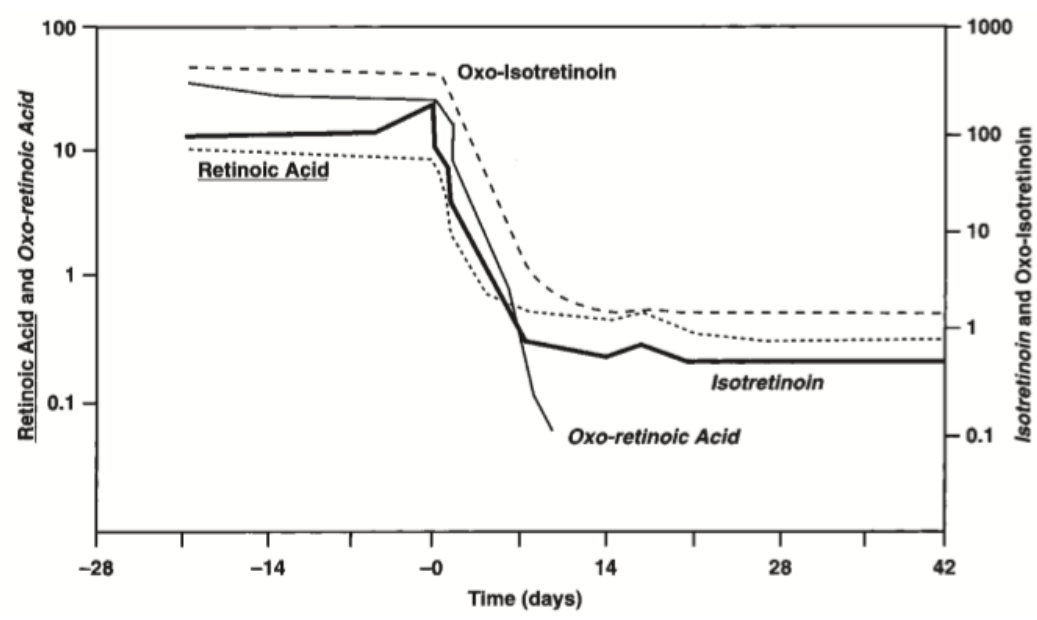

Fig. 1: Mean plasma concentrations of isotretinoin and its metabolite at the last $4 \mathrm{w}$ of treatment (days 28 to 0 ) with oral isotretinoin (oral dose of $30 \mathrm{mg} / \mathrm{day}$ ), and at $6 \mathrm{w}$ after completion of therapy (days 0 to 42) [10,11]

Table 2 below shows some pharmacokinetic parameters of isotretinoin obtained from studies in patients with acne, while data on retinoic acid were collected from studies in healthy individuals receiving retinoic acid $[10,12]$.

Table 2: Pharmacokinetic parameters of isotretinoin and its metabolites

\begin{tabular}{llll}
\hline & Isotretinoin & Oxo-isotretinoin & Retinoic acid* \\
\hline Half-life (d) & $18.7 \pm 6.2$ & $29.2 \pm 5.7$ & $0.9 \pm 0.4$ \\
Cmax (ng/ml) & $208 \pm 91.8$ & $473.2 \pm 171.3$ & $22.4 \pm 15.0$ \\
Cmin (ng/ml) & $89.9 \pm 48.7$ & $387.9 \pm 152.1$ & $11.2 \pm 5.6$ \\
Tmax (d) & $4.5 \pm 3.4$ & $6.8 \pm 6.5$ & $4.5 \pm 3.3$ \\
\hline
\end{tabular}

*Pharmacokinetic parameters when all-trans retinoic acid is administered directly to patients

Isotretinoin has been reported to have several interactions with other drugs, such as alcohol, fungistatic imidazole, salicylic acid, indomethacin, carbamazepine, oral tetracycline, and vitamin A [8].
A literature reported a decline of efficacy when isotretinoin is taken together with large amounts of alcohol. Also, its concentration will increase if combined with fungistatic imidazole [8]. This occurs due to the metabolism of isotretinoin by the enzyme cytochrome P450, 
in which ethanol is its inducer. As a result, the metabolism of isotretinoin increases while its efficacy decreases.

In addition, the antifungal class of imidazole is an inhibitor of this isoenzyme, thus decreasing isotretinoin metabolism. Therefore, its concentration in the blood increases, provoking the risk of toxicity [8].

Isotretinoin is distributed in the blood bound to albumin. Its distribution will be disrupted if there is consumption of drugs that are acidic and have a high affinity for albumin; for instance, salicylic acid and indomethacin [8].

If these drugs concentrations are high enough in the blood, it can substitute isotretinoin from protein binding, thus increasing the amount of unbound drug concentration. Carbamazepine plasma level decreases when taken with isotretinoin. Hence, careful monitoring should be done in epileptic patients taking carbamazepine with isotretinoin. Combination of oral tetracycline and isotretinoin should be avoided since it may trigger intracranial hypertension. Lastly, supplements containing vitamin A should not be taken together with isotretinoin due to possible additive toxic effects [8].

\section{Isotretinoin mechanism of action}

Isotretinoin is known to be the only treatment modality that has implications for the entire pathogenesis of acne. The mechanism of action of isotretinoin is mediated through its role in cell cycle and differentiation, immune function, and apoptosis [13-19].

Retinoid plays a role through nuclear interactions with retinoic acid receptors (RARs), which are ligand-dependent transcription factors. In other words, the regulation of gene transcription solely occurs through the interaction of retinoid composition with the receptors. These receptors can be activated from various retinoid forms, their metabolites, and isomers with differences in binding affinity. RARs bind to 9-cis-trans-retinoic acid and two major natural vitamin $\mathrm{A}$ derivatives, whereas retinoid $\mathrm{x}$ receptors (RXRs) only bind to 9-cistrans-retinoic acid. Retinoid can induce or suppress the expression of various genes and play an essential role in the cellular process. The mechanism of action includes normalizing follicular hyperkeratinization, decreasing the production of cytokeratin 1, 10, 14, filaggrin, matrix metallopeptidases (MMPs), and toll-like receptor 2 (TLR-2), and increasing the production of cytokeratin 7 , 13,19 , laminina B1, and IL-1 $[9,20]$.

Therefore, retinoid contributes to decreasing corneocytes' adhesion, supporting cellular proliferation and follicular renewal, induction of cell apoptosis, and immune regulation [9].

Through these mechanisms, isotretinoin may alter comedogenesis, decrease sebum production and colonization of Propionibacterium acnes, and promote anti-inflammatory effects [8]. Isotretinoin affects comedogenesis by reducing hyperkeratinization through a mechanism that is still unknown [21-23]. To date, there is still no evidence proving the effects of isotretinoin on keratinocyte metabolism [3]. Furthermore, it is known that isotretinoin does not have a direct antimicrobial mechanism. Isotretinoin lessens the rate of sebum excretion and the size of pilosebaceous ducts, making the skin environment less favorable for $P$. acnes. In addition, isotretinoin can also improve host defense mechanisms and modify chemotaxis monocytes to produce anti-inflammatory effects. The significant reduction in $P$. acnes population also contributes to the decline in acne inflammation [8].

\section{Effectiveness of AV therapy with isotretinoin}

Initially, isotretinoin is only indicated for nodulocystic AV cases. However, it is recently used for moderate to severe AV that does not respond well to topical combination therapy or systemic antibiotics [24]. Table 3 outlines some of the results from clinical trials of isotretinoin.

Table 3: Effectiveness of AV therapy with isotretinoin in various studies

\begin{tabular}{|c|c|c|c|c|c|c|c|c|c|c|}
\hline & Author & Year & $\begin{array}{l}\text { Samples size } \\
\text { and } \\
\text { characteristics }\end{array}$ & $\begin{array}{l}\text { Isotretinoin } \\
\text { dosage }\end{array}$ & $\begin{array}{l}\text { Duration of } \\
\text { therapy/ } \\
\text { research } \\
\text { intervention }\end{array}$ & $\begin{array}{l}\text { Measured } \\
\text { parameter }\end{array}$ & Results & Adverse events & $\begin{array}{l}\text { Level of } \\
\text { evidence } \\
\text { and } \\
\text { grade of } \\
\text { recomm- } \\
\text { endation } \\
\end{array}$ & Ref \\
\hline 1 & $\begin{array}{l}\text { Nadia } \\
\text { and El- } \\
\text { Sherif et } \\
\text { al. }\end{array}$ & 2013 & $\begin{array}{l}75 \text { patients with } \\
\text { moderate AV }\end{array}$ & $\begin{array}{l}\text { Group 1: } \\
1 \times 20 \mathrm{mg} \\
\text { isotretinoin } \\
\text { Group 2: } \\
\text { 2x20 mg } \\
\text { isotretinoin }\end{array}$ & For $7 \mathrm{~d}$ in $1 \mathrm{mo}$ & $\begin{array}{l}\text { Acne lesion } \\
\text { count, total } \\
\text { load of acne, } \\
\text { an } \\
\text { examination } \\
\text { of acne } \\
\text { severity, and } \\
\text { side effects }\end{array}$ & $\begin{array}{l}\text { Both regimens } \\
\text { are safe and } \\
\text { effective for } \\
\text { moderate AV. } \\
\text { Intermittent } \\
\text { regimen can be } \\
\text { cost-effective } \\
\text { alternatives. }\end{array}$ & $\begin{array}{l}\text { Cheilitis in } 81,3 \% \text { and } \\
68,6 \% \text {, respectively. }\end{array}$ & $1 \mathrm{~A}$ & [25] \\
\hline 2 & $\begin{array}{l}\text { Kaymak } \\
\text { and Ilter } \\
\text { et al. }\end{array}$ & 2005 & $\begin{array}{l}60 \text { patients with } \\
\text { mild to } \\
\text { moderate AV }\end{array}$ & $\begin{array}{l}0,5-0,75 / \mathrm{kg} \\
\text { per day for } 1 \\
\text { w out of } 4 \mathrm{w}\end{array}$ & $6 \mathrm{mo}$ & $\begin{array}{l}\text { Acne severity } \\
\text { and total acne } \\
\text { lesion }\end{array}$ & $\begin{array}{l}\text { Intermittent } \\
\text { isotretinoin is } \\
\text { safe and effective } \\
\text { for mild to } \\
\text { moderate AV. }\end{array}$ & $\begin{array}{l}\text { All side effects are } \\
\text { mild; there is no need } \\
\text { for drug } \\
\text { discontinuation. } \\
\text { Cheilitis } 41 \% \text {, acne } \\
\text { activation } 38 \% \text {. }\end{array}$ & $1 \mathrm{~A}$ & [26] \\
\hline 3 & $\begin{array}{l}\text { Amichai } \\
\text { et al. }\end{array}$ & 2006 & $\begin{array}{l}638 \text { patients } \\
\text { with moderate } \\
\text { AV }\end{array}$ & $\begin{array}{l}20 \mathrm{mg} / \mathrm{per} \\
\text { day or low } \\
\text { dose regimen } \\
(0,3-0,4 \\
\mathrm{mg} / \mathrm{kg} \text { per } \\
\text { day) }\end{array}$ & $6 \mathrm{mo}$ & & $\begin{array}{l}\text { Low dose } \\
\text { isotretinoin for } 6 \\
\text { mo is effective } \\
\text { for moderate } \\
\text { acne, minimal } \\
\text { side effects, and } \\
\text { lower cost } \\
\text { compared to } \\
\text { higher dose. }\end{array}$ & $\begin{array}{l}\text { Cheilitis }(91 \%) \text {, mild } \\
\text { xerosis }(43 \%), \\
\text { epistaxis }(2,5 \%) \text {, } \\
\text { elevated liver enzymes } \\
\text { (4.85), elevated serum } \\
\text { lipids }(4.2 \%) .\end{array}$ & 1B & [27] \\
\hline 4 & $\begin{array}{l}\text { Shetti et } \\
\text { al. }\end{array}$ & 2017 & $\begin{array}{l}100 \text { patients } \\
\text { with moderate } \\
\text { to severe } \mathrm{AV}\end{array}$ & $\begin{array}{l}\text { Group } 1: 20 \\
\text { mg of } \\
\text { isotretinoin } \\
\text { once a day } \\
\text { Group } 2: 20 \\
\text { mg of } \\
\text { isotretinoin } \\
\text { once a day for } \\
7 \text { d out of } 1 \\
\text { mo }\end{array}$ & $4 \mathrm{mo}$ & $\begin{array}{l}\text { Global Acne } \\
\text { Grading } \\
\text { System } \\
\text { (GAGS), } \\
\text { patient } \\
\text { satisfaction }\end{array}$ & $\begin{array}{l}\text { Clinically } \\
\text { significant } \\
\text { improvement } \\
\text { between group } 1 \\
\text { and } 2 \text {. }\end{array}$ & - & $1 \mathrm{C}$ & [24] \\
\hline 5 & Costa et al. & 2019 & $\begin{array}{l}3836 \\
\text { patients } \\
\text { with }\end{array}$ & $\begin{array}{l}\text { Group 1: oral } \\
\text { isotretinoin } \\
\text { Group 2: oral }\end{array}$ & $\begin{array}{l}\text { Minimum } \\
\text { period of } 16 \mathrm{w}\end{array}$ & $\begin{array}{l}\text { Decreased } \\
\text { inflammatory } \\
\text { lesion count }\end{array}$ & $\begin{array}{l}87 \text { per } 100 \\
\text { comparative risk } \\
\text { (with } 95 \% \mathrm{Cl} \text { ). }\end{array}$ & $\begin{array}{l}\text { No serious side effect } \\
\text { is reported. }\end{array}$ & $1 \mathrm{~A}$ & [28] \\
\hline
\end{tabular}




\begin{tabular}{|c|c|c|c|c|c|c|c|c|c|c|}
\hline & & & $\begin{array}{l}\text { moderate to } \\
\text { severe } \mathrm{AV}\end{array}$ & antibiotic & & & $\begin{array}{l}\text { For oral } \\
\text { antibiotics with } \\
\text { other topical } \\
\text { agents, } 86 \text { per } \\
100 .\end{array}$ & & & \\
\hline 6 & Akman et al. & 2007 & $\begin{array}{l}66 \text { patients } \\
\text { with } \\
\text { moderate to } \\
\text { severe } \mathrm{AV}\end{array}$ & $\begin{array}{l}0,5 \\
\mathrm{mg} / \mathrm{kg} / \text { day }\end{array}$ & $5-6 \mathrm{mo}$ & $\begin{array}{l}\text { Global FDA } \\
\text { grade, } \\
\text { inflammatory } \\
\text { lesions, and } \\
\text { non- } \\
\text { inflammatory } \\
\text { lesions }\end{array}$ & $\begin{array}{l}\text { Oral isotretinoin } \\
\text { is effective in } \\
\text { both regular and } \\
\text { intermittent } \\
\text { doses. }\end{array}$ & $\begin{array}{l}\text { Side effects are minor } \\
\text { and mild. }\end{array}$ & $1 \mathrm{~A}$ & [29] \\
\hline 7 & $\begin{array}{l}\text { Rademaker } \\
\text { et al. }\end{array}$ & 2014 & Mild acne & $\begin{array}{l}\text { Low dose } \\
\text { isotretinoin } \\
\text { (5 mg/day) }\end{array}$ & $42 w$ & $\begin{array}{l}\text { Acne lesion } \\
\text { count }\end{array}$ & $\begin{array}{l}\text { Use of } \\
\text { isotretinoin, for } \\
16-32 \mathrm{w} \text { is very } \\
\text { effective for } \\
\text { adult AV. }\end{array}$ & $\begin{array}{l}\text { Good safety profile, } \\
\text { indicated by mild side } \\
\text { effects, mostly mild } \\
\text { and short-lived } \\
\text { dryness of mucous } \\
\text { membrane. }\end{array}$ & $1 \mathrm{~A}$ & [7] \\
\hline 8 & $\begin{array}{l}\text { Piquero et } \\
\text { al. }\end{array}$ & 2002 & $\begin{array}{l}\text { Patients } \\
\text { with } \\
\text { moderate to } \\
\text { severe AV }\end{array}$ & $\begin{array}{l}\text { Low dose } \\
\text { isotretinoin } \\
0.2-0.3 \\
\mathrm{mg} / \mathrm{kg} / \text { day }\end{array}$ & $12 \mathrm{mo}$ & & $\begin{array}{l}\text { Excellent } \\
\text { therapeutic } \\
\text { response of more } \\
\text { than } 80 \% \text {. }\end{array}$ & & $1 \mathrm{~A} 1$ & [30] \\
\hline
\end{tabular}

Most of the patients receiving oral isotretinoin were acne-free after 4-6 mo of treatment, depending on the dose. Recent clinical experience suggests that long-term recovery rates can be lower than previously thought [31-34].

\section{Contraindication}

Contraindications for isotretinoin include pregnancy, breastfeeding, hepatic dysfunction, uncontrolled hyperlipidemia, hypervitaminosis $\mathrm{A}$, and renal insufficiency [35]. Isotretinoin falls into Category $\mathrm{X}$ drugs and should not be taken by patients who are pregnant or who may become pregnant. Isotretinoin has been reported to cause severe congenital abnormalities. In 2005, The Food and Drug Administration issued a recommendation in the US for both women and men taking oral isotretinoin to be registered on the national 'iPLEDGE' program. As a mandatory regulatory program in the United States, the 'iPLDGE' program needs to be completed prior to distributing isotretinoin to prevent the use of this drug during pregnancy to prevent teratogenicity [36]. This requirement is aimed at women of reproductive age with regulations as follows: two negative pregnancy tests prior to prescription, negative pregnancy test every month for each isotretinoin prescription, and documented abstinence or use of contraception. Moreover, signature confirmation is required to confirm that patients have fully understood the possible adverse events such as depression and suicidal thoughts. Isotretinoin is also contraindicated in patients who are hypersensitive to its components, such as vitamin A and its preservatives [37, 38].

\section{Side effects and monitoring}

Although isotretinoin may induce many side effects, they are predictable and rarely affect patient's therapy. The reported side effects of oral isotretinoin range widely, from mucocutaneous effects, including dryness and cracking of lips and skin, to teratogenicity [39]. Isotretinoin may also impact the sebaceous glands and reduce gland activity, size, and decrease sebum production. Mucocutaneous effects from isotretinoin are dose-dependent and generally well tolerated with dosage modification and additional symptomatic therapy [8]. Dry oral mucosa can occur in almost any patient within a few days after initiation of treatment. Dry skin, facial patches, or irritation are reported in 1:5 patients and occur in the first $4 \mathrm{w}$ when acne flares are frequently reported. Nasal dryness also occurs in $30-50 \%$ of patients.
Nevertheless, mucocutaneous side effects can be controlled with the routine use of moisturizers $[8,40]$.

Excessive mucocutaneous dryness may lead to retinoid dermatitis, severe retinoid cheilitis, or conjunctivitis as complications from secondary $S$. aureus infection. These symptoms need to be treated with moderate to strong potency steroid ointment in combination with antiseptic. If impetiginization occurs, anti-staphylococcal therapy such as mupirocin $2 \%$ ointment should be used [8]. If visual disturbances are present, patients should immediately discontinue the treatment and be examined by an ophthalmologist [27].

The most fatal adverse event that may occur is teratogenicity. Clinicians need to inquire pregnancy plans in individuals taking isotretinoin and provide informed consent [8].

Taking isotretinoin $30 \mathrm{~d}$ before and during pregnancy has been reported to cause fetal or neonatal problems (above $16 \mathrm{w}$ of gestation), such as fetal death in the uterus, congenital birth defects, and neural tube defects. Congenital anomalies include abnormalities of the skin, abdominal wall, cardiovascular, digestive, nervous, musculoskeletal, respiratory, and urogenital system, as well as multiple chromosomal anomalies/ syndromes and other congenital malformations [41, 42].

Mood changes and depression are also common in patients taking isotretinoin. A cross-over controlled case study demonstrated a 2.68 relative risk of depression (95\% CI: 1,03 to 3,89) for acne patients taking oral isotretinoin. However, this report is still considered contradictory to other studies. Therefore, mood changes and depression symptoms are required to be asked and monitored in every visit [8]. Due to the possibility of developing cerebral pseudotumor, isotretinoin is contraindicated when combined with many other medications, including tetracycline. Tetracycline, including doxycycline and minocycline, must not be prescribed with isotretinoin as both drugs can cause intracranial hypertension. Headache can be one of the prodromal symptoms. Systemic side effects generally can be repressed by decreasing dosage and using NSAIDs or aspirin [8].

Table 4: The prevalence of frequent side effects by dose (absolute number and percentage of patients by dose groups)

\begin{tabular}{ll}
\hline Side effects & Number of patients (\%) \\
\hline Infection & $45(2.6)$ \\
Abnormal serum lipid & $45(2.5)$ \\
Others & $45(2.5)$ \\
Late response to treatment & $39(2.2)$ \\
Periungual granuloma & $37(2.1)$ \\
Significantly abnormal liver function & $20(1.1)$ \\
Sensitivity to sunlight & $17(1.0)$ \\
Headache & $15(0.7)$ \\
Gastrointestinal symptoms & $6(0.3)$ \\
Pregnancy & $2(0.1)$ \\
\hline
\end{tabular}


Acute flare during the initial use of isotretinoin may occur in $6 \%$ of cases, with predisposing risk factors including macro comedones and nodules. Flare can be very severe and cause physical and psychological limitations. If flare develops, oral prednisolone should be prescribed at a dose of $0.5-1 \mathrm{mg} / \mathrm{kg} /$ day for $2-3 \mathrm{w}$ and can be tapered off slowly over $6 \mathrm{w}$. In addition, isotretinoin consumption needs to be discontinued or use a dose of $0.25 \mathrm{mg} / \mathrm{kg} / \mathrm{day}$, depending on the severity [8].

Results from a retrospective study of 1743 participants that evaluated the prevalence of isotretinoin side effects are shown in table 4 and table 5 [43].

Table 5: Other side effects

\begin{tabular}{|c|c|c|c|c|c|c|}
\hline & \multicolumn{6}{|l|}{ Dosage } \\
\hline & $\begin{array}{l}\text { Very low }(0-0.25) \\
\mathrm{N}=450(\%)\end{array}$ & $\begin{array}{l}\text { Low }(0.26-0.50) \\
N=471(5)\end{array}$ & $\begin{array}{l}\text { Medium (0.51-0.75) } \\
\mathrm{N}=119\end{array}$ & $\begin{array}{l}\text { High }(0.76-1.0) \\
N=703(\%)\end{array}$ & $\begin{array}{l}\text { Total } \\
N=1743(\%)\end{array}$ & Ref \\
\hline Cheilitis & $212(47.1)$ & $365(77.5)$ & $112(94.1)$ & $678(96.4)$ & $1367(78.4)$ & {$[27]$} \\
\hline Eczema & $33(7.5)$ & $45(9.6)$ & $22(18.5)$ & 111 (15.8) & $211(12.1)$ & \\
\hline Tiredness & $25(5.5)$ & $36(7.6)$ & $24(20.2)$ & $126(17.9)$ & $211(12.1)$ & \\
\hline Mood changes & $21(4.7)$ & $21(4.5)$ & $13(10.9)$ & $69(9.8)$ & $124(7.1)$ & \\
\hline Skin fragility & $15(3.3)$ & $17(3.6)$ & $7(5.8)$ & $67(9.5)$ & $106(6.1)$ & \\
\hline Nose bleeds & $9(2.0)$ & $17(3.6)$ & $6(4.2)$ & $58(8.2)$ & $90(5.2)$ & \\
\hline Muscle aches & $10(2.2)$ & $12(2.5)$ & $5(4.2)$ & $43(26.1)$ & $70(4.0)$ & \\
\hline Eye problems & $10(2.2)$ & $10(2.1)$ & $6(5.0)$ & $34(4.8)$ & $60(3.4)$ & \\
\hline
\end{tabular}

Due to the various side effects that might arise, further clinical and laboratory assessments are needed to monitor response to therapy and the safety of oral isotretinoin. The need to monitor serum transaminase, liver function, and serum lipid during therapy is still under debate. Elevation of these tests occurred in almost all patients, and they quickly returned to initial levels as soon as therapy was terminated. Nevertheless, it is important to conduct these tests before therapy is initiated. Previous studies have stated it is unnecessary to repeat laboratory tests during treatment, except in high-risk populations such as patients with diabetes and familial hypertriglyceridemia. However, the European Directive recommended assessing liver enzyme tests and lipid profile at baseline, at $1 \mathrm{mo}$, and 3 mo after initiation of therapy [8]. Monitoring of triglyceride level is conducted specifically to avoid the incidence of pancreatitis correlated with hypertriglyceridemia, although it does not often occur [44]. Prior to therapy, assessments include liver function tests, fasted lipid profile (including triglyceride level), blood glucose, creatinine, and complete blood count with differential counts. Screening for mood changes, psychosis, aggression, suicidal thoughts, skin changes, and visual changes can also be conducted prior to therapy $[23,24]$.

It is important to list down the components that need to be evaluated before therapy, evaluations that need to be repeated during therapy, and the frequency or intervals for conducting those evaluations. It could all be written down on one table and be given a subtitle "side effects". For example, as isotretinoin can disrupt fat metabolism, it is essential to assess lipid profile prior to therapy. Evaluations needed prior to and during oral isotretinoin therapy are written in the table below (table 6).

Table 6: Evaluations needed prior to and during oral isotretinoin therapy

\begin{tabular}{llll}
\hline Evaluation & Prior to therapy & 1 mo after therapy started & 3 mo after therapy started \\
\hline Complete blood count & $\sqrt{ }$ & & \\
Blood glucose & $\sqrt{ }$ & & $\sqrt{ }$ \\
Creatinine & $\sqrt{ }$ & $\sqrt{ }$ & $\sqrt{ }$ \\
Liver function & $\sqrt{ }$ & $\sqrt{ }$ & $\sqrt{ }$ \\
Lipid profile & $\sqrt{ }$ & $\sqrt{ }$ & \\
Mood changes & $\sqrt{ }$ & \\
\hline
\end{tabular}

The consequences of this strict regulation may decrease the use of isotretinoin, which may be a disadvantage for patients that actually need this therapy. On the other side, restriction of isotretinoin use as a second-line therapy can lead to acne scar formation that could affect the quality of life.

Expert opinion backed by clinical data supported the use of isotretinoin for acne vulgaris patients with moderate severity that for any reason did not respond to conventional therapy. Acne can lead to scarring in $30 \%$ of acne with moderate severity and significant psychological morbidity in $12-13 \%$ of cases $[8,45]$.

\section{CONCLUSION}

Isotretinoin is one of the treatment modalities for acne with good effectivity and has been used as standard acne management in many countries due to its mechanism of actions that affect the entire acne pathogenesis. Considering the various side effects of isotretinoin ranging from mild to severe, its use requires adequate clinical assessment and monitoring by a dermatologist.

\section{ACKNOWLEDGMENT}

The author would like to thank the staffs of Cosmetic Dermatology Division Department of Dermatology and Venereology Faculty of Medicine Universitas Indonesia for the facilities provided to carry out the review.

\section{AUTHORS CONTRIBUTIONS}

The author contributed fully to this review article.

\section{CONFLICT OF INTERESTS}

\section{Declared none}

\section{REFERENCES}

1. Wahab MA, Rahman MH, Monamie NS, Jamaluddin M, Khondker L, Afroz W. Isotretinoin versus weekly pulse dose azithromycin in the treatment of acne-a comparative study. J Pakistan Assoc Dermatol 2008;18:9-14.

2. Ayanoglu BT, Demirdag HG, Armagan BY, Bezirgan 0 . Perceptions about oral isotretinoin treatment. Dermatol Ther 2009;32:e12873. 
3. Brzenzinski P, Borowska K, Chiriac A, Smigielski J. Adverse effects of isotretinoin: a large, retrospective review. Dermatol Ther 2017;30:e12483.

4. Bettoli V, Guerra Tapia A, Herane MI, Piquero Martin J. Challenges and solutions in oral isotretinoin in acne: reflections on $35 \mathrm{y}$ of experience. Clin Cosmet Investig Dermatol 2019;12:943-51.

5. Lehmann HP, Robinson KA, Andrews JS, Holloway V, Goodman SN. Acne therapy: a methodologic review. J Am Acad Dermatol 2002;47:231-40.

6. Zanglein AL, Pahy A, Scholsser BJ, Alikhan A, Baldwin HE, Berson DS, et al. Guidelines of care for the management of acne vulgaris. J Am Acad Dermatol 2016;74:945-73.

7. Rademaker M, Wishart JM, Birchall NM. Isotretinoin $5 \mathrm{mg}$ daily for a low-grade adult can vulgaris-a placebo-controlled, randomized double-blind study. J Eur Acad Dermatol Venereol 2014;28:747-54.

8. Layton A. The use of isotretinoin in acne. Dermatoendocrinol 2009;1:162-9.

9. Bagatin E, Costa CS. The use of isotretinoin for acne-an update on optimal dosing, surveillance, and adverse effects. Expert Rev Clin Pharmacol 2020;13:885-97.

10. Wiegand UW, Chou RC. Pharmacokinetics of oral isotretinoin. J Am Acad Dermatol 1998;39 Suppl 2:S8-12.

11. Wyss R, Bucheli F. Quantitative analysis of retinoids in biological fluids by high-performance liquid chromatography using column switching: I. Determination of isotretinoin and tretinoin and their 4-oxo metabolites in plasma. J Chromatogr 1988;424:303-14.

12. Lefebvre P, Thomas G, Gourrnel B. Pharmacokinetics of oral alltrans-retinoic acid in patients with acute promyelocytic leukemia. Leukemia 1991;5:1054-8.

13. Fogh K, Voorhees JJ, Astrom A. Expression, purification and binding properties of human cellular retinoic acid-binding protein type I and II. Arch Biochem Biophys 1993;300:751-5.

14. Allenby G, Bocquel MT, Saunders M, Kazmer S, Speck J, Rosenberger $\mathrm{M}$, et al. Retinoic acid receptors and retinoid $\mathrm{X}$ receptors: interactions with endogenous retinoic acids. Proc Natl Acad Sci USA 1993;90:30-4.

15. Levin AA, Bosakowski T, Kazmer S, Grippo JF. 13-cis retinoic acid does not bind to retinoic acid receptors alpha, beta and gamma. Toxicologist 1992;12:181.

16. Ott F, Bollag W, Geiger JM. Oral 9-cis-retinoic acid versus 13cis-retinoic acid in acne therapy. Dermatology 1996;193:124-6.

17. Geiger JM, Hommel L, Harms M, Saurat JH. Oral 13-cis-retinoic acid is superior to 9-cis-retinoic acid in sebosuppression in human beings. J Am Acad Dermatol 1996;34:513-5.

18. Tsukada M, Schröder M, Roos TC, Chandraratna RA, Reichert U, Merk HF, et al. 13-cis-retinoic acid exerts its specific activity on human sebocytes through selective intracellular isomerization to all-trans-retinoic acid and binding to retinoid acid receptors. J Invest Dermatol 2000;115:321-7.

19. Nelson AM, Gilliland KL, Cong Z, Thiboutot DM. 13-cis-retinoic acid induces apoptosis and cell cycle arrest in human SEB-1 sebocytes. J Invest Dermatol 2006;126:2178-89.

20. Al-Abadie M, Oumeish F, Al-Rubaye M, Rafiq S, Ball PA, Morrissey H. Vitamin A derivatives use in the treatment of skin conditions. Int J Curr Pharm Sci 2020;12:9-12.

21. Knutson DD. Ultrastructural observations in acne vulgaris: the normal sebaceous follicle and lesions. J Invest Dermatol 1974;62:288-307.

22. Plewig G, Dressel H, Pfleger M, Michelsen S, Kligman AM. Lowdose isotretinoin combined with tretinoin is effective to correct abnormalities of acne. J Dtsch Dermatol Ges 2004;2:31-45.

23. Dalziel $K$, Barton $S$, Marks $R$. The effects of isotretinoin on follicular and sebaceous gland differentiation. Br J Dermatol 1987; $117: 317-23$

24. Shetti SA, Nagesh HN, Hanumantharaya N. A randomized, openlabel, comparative study of the efficacy of low-dose continuous versus low-dose intermittent oral isotretinoin therapy in moderate-to-severe acne vulgaris. Natl J Physiol Pharm Pharmacol 2017;7:941-6.

25. El-Sherif NA, Greiw AS, Benamer AM. Efficacy of low dose versus intermittent isotretinoin regimens in patients with moderate acne vulgaris: a randomized controlled trial. Ibnosina J Med Biomed Sci 2013;5:296-302.

26. Kaymak Y, Ilter N. The effectiveness of intermittent isotretinoin treatment in mild or moderate acne. J Eur Acad Dermatol Venereol 2006;20:1256-60.

27. Amichai B, Shemer A, Grunwald MH. Low-dose isotretinoin in the treatment of acne vulgaris. J Am Acad Dermatol 2006;54:644-6.

28. Costa CS, Bagatin E, Matimbianco ALC, da Silva EMK, Lucio MM, Magin P, et al. Oral isotretinoin for acne. Cochrane Database Syst Rev 2018:CD009435. DOI:10.1002/14651858. CD009435.pub2

29. Akman A, Durusoy C, Senturk M, Koc CK, Soyturk D, Alpsoy E. Treatment of acne with intermittent and conventional isotretinoin: a randomized, controlled, multicenter study. Arch Dermatol Res 2007;299:467-73.

30. Piquero Martin J, Misticone S, Piquero Casals V, Piquero Casals J. Topic therapy-mini isotretinoin doses vs topic therapysystemic antibiotics in the moderate acne patients. Ann Dermatol Venereol 2002;129:S382.

31. Strauss JS, Rapini RP, Shalita AR, Konecky E, Pochi PE, Comite $\mathrm{H}$, et al. Isotretinoin therapy for acne: results of a multicenter dose-response study. J Am Acad Dermatol 1994;10:490-6.

32. Shalita AR. Acne revisited. Arch Dermatol 1994;130:363-4.

33. Layton AM, Knaggs H, Taylor J, Cunliffe WJ. Isotretinoin for acne vulgaris-10 y later: a safe and successful treatment. Br J Dermatol 1993;129:292-6.

34. Azoulay L, Oraichi D, Berard A. Isotretinoin therapy and the incidence of acne relapse: a nested case-control study. $\mathrm{Br} \mathrm{J}$ Dermatol 2007;157:1240-8.

35. Prevost N, English J. Isotretinoin: update on controversial issues. J Pediatr Adolesc Gynecol 2013;26:290-3.

36. Charrow A, Xia FD, Lu J, Waul M, Joyce C, Mostaghimi A. Differences in isotretinoin start, interruption, and early termination across race and sex in the iPLEDGE era. PLoS One 2019;14:e0210445.

37. Zaenglein AL, Pathy AL, Schlosser BJ, Alikhan A, Baldwin HE, Berson DS, et al. Guidelines of care for the management of acne vulgaris. J Am Acad Dermatol 2016;74:945-73.

38. Eichenfield LF, Krakowski AC. A novel patient support program to address isotretinoin adherence: proof-of-concept analysis. J Drugs Dermatol 2015;14:375-9.

39. Tripathi SV, Gustafson CJ, Huang KE, Feldman SR. Side effects of common acne treatments. Expert Opin Drug Saf 2013;12:39-51.

40. McLane J. Analysis of common side effects of isotretinoin. J Am Acad Dermatol 2001;45:S188-94.

41. Zomerdijk IM, Ruiter R, Houweling LMA, Herings RMC, Sturkenboom MCJM, Straus SMJM, et al. Isotretinoin exposure during pregnancy: a population-based study in the netherlands. Br Med J Open 2014;4:e005602.

42. Premchandran D, Madhyastha S, Sahu S, Joy T, Rachana K. Effect of prenatal isotretinoin on postnatal development of rat retina and expression of doublecortin positive cells: a morphometric and histopathological analysis. Int J Pharm Pharm Sci 2014;6:622-6.

43. Rademaker M. Adverse effects of isotretinoin: a retrospective review of 1743 patients started on isotretinoin. Australas J Dermatol 2010;51:248-53.

44. Opel D, Kramer ON, Chebvalier M, Bigby M, Albrecht J. Not every patient needs a triglyceride check, but all can get pancreatitis: a systematic review and clinical characterization of isotretinoinassociated pancreatitis. Br J Dermatol 2017;177:960-6.

45. Tanngoen P, Lamlertthon S, Tiyaboonchai W. Effects of alphamangostin and citronella oil against acne-causing bacteria. Int J Pharm Pharm Sci 2019;11:45-9. 